Meta

Journal des tradlucteurs

Translators' Journal

\title{
French-Canadian Literature in Translation
}

\section{Philip Stratford}

Volume 13, numéro 4, décembre 1968

URI : https://id.erudit.org/iderudit/004306ar

DOI : https://doi.org/10.7202/004306ar

Aller au sommaire du numéro

Éditeur(s)

Les Presses de l'Université de Montréal

ISSN

0026-0452 (imprimé)

1492-1421 (numérique)

Découvrir la revue

Citer cet article

Stratford, P. (1968). French-Canadian Literature in Translation. Meta, 13(4),

180-187. https://doi.org/10.7202/004306ar d'utilisation que vous pouvez consulter en ligne.

https://apropos.erudit.org/fr/usagers/politique-dutilisation/ 


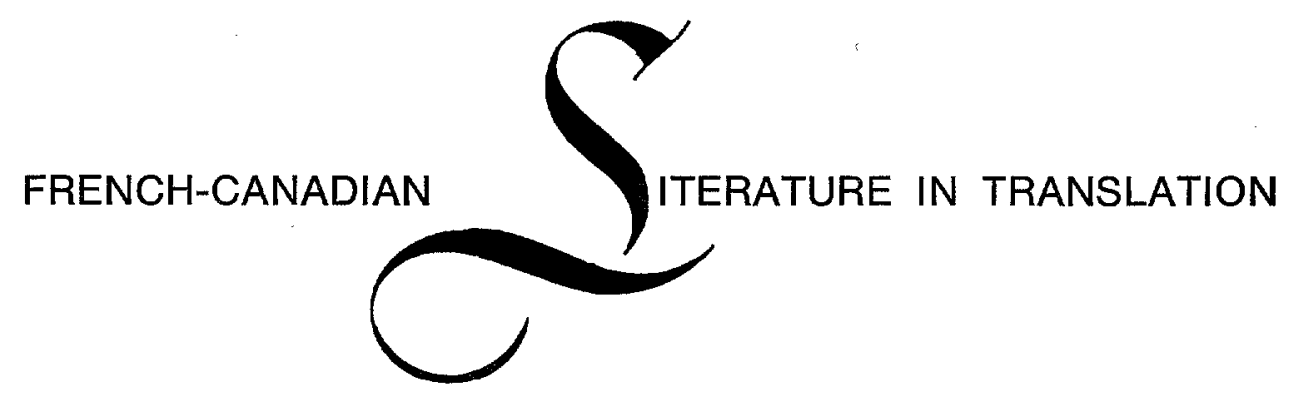

This is a position paper on the state of French-Canadian literature in English translation. It is not an exhaustive survey; it is rather a series of probes made here and there which taken together give a fair picture of the situation at the present moment. The central document in this presentation is a selected bibliography of French-Canadian works that have appeared in translation ${ }^{1}$. In conclusion I make several recommendations as to ways in which Canadian English teachers might interest themselves in this subject ${ }^{2}$.

The most positive thing I can say about French-Canadian literature in translation is by way of something relatively negative: there is much more of it than there is English-Canadian literature translated into French.

I was recently asked to prepare some lectures on English-Canadian literature for an adult education group at the University of Montreal. Only two conditions were imposed: that I should talk about the novel, and that I should use authors whom my audience could read in translation, for while their interest was keen, their English was less so.

The choice was simple. Only two living Anglo-Canadian novelists of note had been translated: Hugh MacLennan and Mordecai Richler. For Richler the choice of the novel was elementary; there was only one, l'Apprentissage de Duddy Kravitz. For MacLennan the choice was much more complex, for three of his six novels had been translated: Two Solitudes (translated in France), Barometer Rising and The Watch That Ends the Night (both translated within the last two years by French-Canadian novelist Jean Simard). Apart from these four books, if we except two by Malcolm Lowry whose Canadian status is doubtful, and a few potboilers, no other important English-Canadian novel has been translated since the Jalna books, which represent modern English-Canadian writing almost as well as Maria Chapdelaine does contemporary Quebec. On the overall, going back

1. Cf. p. 185.

2. This paper was read at the first annual convention of the Canadian Council of Teachers of English held at Calgary, August 21-24, 1968. 
to the $19^{\text {th }}$ century, I found twelve English-Canadian novels translated, which makes about one every fifteen years, although the rate is improving. What else could it do?

In the reverse direction, from French into English, things are not quite so dismal. Let me present the situation by means of several spot tests.

First, for example, consider McClelland and Stewart's excellent series of Canadian classics, the paperback New Canadian Library. Of the 63 titles in the series to date, 6 are French-Canadian: 4 by Gabrielle Roy, the most translated Quebec writer, and one each by Ringuet (Thirty Acres) and Lemelin (The Town Below).

View the situation from another angle. Since the Governor General's Awards were founded in 1936, there have been 142 prize-winning books, in French and English. Of these, 13 have been translated, 5 from English to French, and 8 from French to English. I am proud to have done two in the latter category myself, but it makes me feel unconscionably pompous to be able to say that, as a relative newcomer, $I$ can already account personally for one-quarter of all the work that has been done in this line over the past thirty years.

Change the perspective once again. In preparation for this talk I wrote to fifteen major English-Canadian publishers, telling them my subject and asking them for titles of French-Canadian literary works either on their current lists or projected for the future. The 12 publishers who replied were able to muster 19 titles among them, 16 presently available, 3 in preparation. Several of them regretted to inform me that they did not publish any French-Canadian books in translation, others had a few titles in history and current affairs but nothing in literature. One reported humorously, \&I regret that we do not have any such books, though our parent company does have the rights to the paperback distribution of Maria Chapdelaine (what else?) in the United States. Because of copyright laws, we do not distribute it in Canada. » A typically Canadian situation! In short, six Canadian publishers account for almost all the literary translation that is done: Clarke Irwin, Harvest House, Macmillan, McClelland and Stewart, Oxford, and Ryerson. But none do very much.

My next check was to write to Naim Kattam, Arts Officer of the Canada Council, to ask him for information, for the majority of translations are subsidized, or have been since 1959, by the Canada Council. I also knew that M. Kattan was particularly interested in this subject because last year he edited a very interesting issue of the French review les Lettres nouvelles dedicated to Canadian Literature, in which half a dozen English-Canadian writers had appeared in translation, most for the first time. M. Kattan prepared a list of grants made for translation, FrenchEnglish and English-French, over the past nine years. The total amount granted was $\$ 105450$ or a little less than $\$ 12000$ a year on the average. If one excepts the two largest grants - $\$ 17000$ made in 1962 for translation of the Dictionary of National Biography, and $\$ 10000$ in 1966 to the Canadian Association of Geographers -, which reduces the list to grants made for translation of works by individual authors, we see that while the average yearly total in 1959-1962 was $\$ 4000$, in the last five years, Centennial helping, this sum has more than tripled. But I must hasten to add that these totals and averages apply to books of 
all kinds, and translations in both directions. Non-literary works, history, geography, economics, etc., take by far the biggest part of the pie. The total amount granted for literature over the nine-year period was $\$ 22900$, or an average of about $\$ 2500$ a year. And if one stays strictly in the domain of grants made for translation from French to English, that is, French-Canadian literature in translation, the average falls to something like $\$ 1900$ a year. A little less.

I am not laying any blame at the door of the Canada Council. Their policy is, when possible, to meet all reasonable demands. I have no reason to believe that many requests for subsidies in aid of translation are turned down. On the other hand, I have a reasonably firm conviction that requests for aid to literary translation have been relatively few. And for the wrong reasons. The right reasons would be that there was such a lively market for French-Canadian literature in translation that there was no need for publishers to ask for government subsidy. The wrong reason, or the brute reality of the case, is that public interest is small, or nascent at best, that publishers are reluctant to run the risk of large scale promotion, and that they include a few titles in translation on their lists as a prestige items in the name of national good will, but find themselves obliged to apply for Council grants to help them make ends meet. There are other reasons besides public apathy for the dearth of translations: lack of competent translators; weak incentives for those there are, since rates for literary translation are so inferior to commercial rates, and so on.

Now despite the gloomy nature of these last remarks, the picture I have been painting is growing gradually a little rosier, and a glance at the bibliography I have prepared may make it seem rosier still. This is a selected bibliography of works in translation, old and new. I have left out certain things of marginal literary value - old historical novels, a few rural idylls, some collections of French-Canadian songs, and the like. The emphasis is on what is of lasting value or contemporary interest. I have divided it into genres, thinking it would be more convenient as a reference tool this way. I should immediately acknowledge the assistance of Professor Michael Gnarowski of Sir George Williäms University who let me consult a similar bibliography which he had prepared for the B \& B Commission in 1964. This document brings his up to date and adds a few items, but it also omits entirely some that he includes, for instance, explorers' journals. And though they are not too numerous in translation, perhaps I should have included them under another genre heading, for I believe, with a great many of my fellow Canadianists that this kind of writing should be considered part and parcel of our literary heritage. But this bibliography is strictly literary in the conventional sense.

My method of entry is simple, if not orthodox: First the French-Canadian author's name, then the original title of his work, followed by the date of first publication. Then follows the translator's name - where $I$ have been able to find it -, the English title, publisher, and date of publication. Where the place of publication is not noted, read Toronto.

It's quite an impressive list, totalling 48 authors and 66 titles. I must confess that it gave a jolt to my initial pessimism to discover that so much had been done. It would be quite possible for an English-speaking student to get a very 
good idea of Quebec literature without ever knowing a word of French, if all these titles were available.

But on closer examination, the opportunity dwindles. For many of the works, poetry especially, all we have in translation are certain selections. Secondly, it is really incorrect to speak of these works as being available; as evidenced by my sampling of publishers' reports, works currently listed are very few, and a great many of the titles in the bibliography are out of print. Thirdly, to be perfectly dour about it, I have made no attempt to judge these works as to quality. I know for a fact that some of them are bad. Read, for example, the article by Patricia Claxton on the translation of Hubert Aquin's Prochain épisode, in the March 1967 META. To be accurate, this is more a record of what might be, or of what has been, than of what is.

That is the end of my position paper. Now what conclusions can we draw from it? Quite obviously, I feel, and feel strongly, that there should be more translation, much more. With no trouble at all I could list twenty French-Canadian titles, both old and new, that deserve to be translated tomorrow. And of course there's no sense waiting for the bilingual millenium. More and more Canadians, hopefully, will become proficient in both languages, and they are entirely within their rights to turn up their noses at translations, preferring, as they will say, to read the works in the original. As a matter of fact that has been the classic excuse used to explain the fact that so few English-Canadian books have been translated into French. The reading classes in Quebec, the argument runs, are nearly all bilingual anyway, so they would not consider buying and reading translations. A very specious argument. Pierre Tisseyre, editor-in-chief of Le Cercle du Livre de France, estimates that $10 \%$ of his readers fall into this category. Then, too, it's a plain fact that even the most bilingual readers still have a preferred reading language. The members of the literary and university élite that I know, while they could read English for pleasure, for the most part do not do so, it remains a latent potential. If that is true of the French, it is probably twice as true of educated English readers in the rest of Canada. It would be interesting to know just how many French-Canadian books are sold to English-Canadian readers, to see the actual sales figures.

No it is an indiscutable fact that a lot more translation would be a great boon to this country. Translation is a bridge between people, and we in Canada desperately need more and better bridges of this kind. In a very real sense, the life and future of our country depends on our communications systems. $\mathrm{CN}$, $\mathrm{CP}, \mathrm{CBC}, \mathrm{NFB}$ - those very familiar and very Canadian ciphers represent our national lifelines. And I would like to see the word translation becomes as household and as vital a word for us as Trans-Canada.

I mean literary translation, of course. Our politicians, our economists, our historians, our royal commissioners get translated. But how much more important in the long run, when it is really a question of knowing another people, how they think, feel, react, imagine and remember, to have our poets, dramatists, and novelists translated, our essayists and journalists. Everyone marvels at the fantastic progress in communications over the last century, generation, or decade. The machines are magnificent, the techniques are intriguing, the theoricians are in 
clover. The only weak link is the quality and diversity of the material that goes into these highly sophisticated systems. To come right down to our Canadian situation, the literary potential of this country could pass from single to double through translation. Quebec writers turn out some 300 books a year, almost as many as all the rest of Canada put together, and yet all these books remain closed books to most of us because we lack a vigourous and intelligently planned policy of translation.

But let's return to the situation at the present moment. As can be seen from the bibliography, some, more and more, French-Canadian books are getting translated. The question that must arise in the minds of teachers in English schools is: Where do such books fit into the curriculum ? The study of French-Canadian texts in the original undoubtedly belongs in French departments, and I hope that the monopoly of classical French literature is being broken, just as the monopoly of British literature is gradually being broken in English studies with the introduction of more and more offerings in American and Canadian literature. I also hope that some enthusiastic French departments are offering non-specialist courses in French-Canadian literature in translation.

But with all due respect for the linguistic and critical competence of our French teachers, I think that there is really only one intelligent place for FrenchCanadian literature in translation in our school curriculums, and that is right in the middle of the English program. English teachers have always been eclectic; they have a longstanding reputation as literary magpies. It is years now since we expropriated Don Quixote, Crime and Punishment, and The Charterhouse of Parma for English literature, and made English authors out of Ibsen, Strindberg, Chekov, Genet, and Ionesco. And we should use exactly the same effrontery in dealing with French-Canadian literature. The place it belongs in the curriculum is side by side with English-Canadian literature in a course called simply « Canadian Literature ». Here, at least, the slogan « equal status» has a concrete meaning. This is a form of assimilation that French-Canadians can have no real objection to. And it is an unique way to enrich our offerings in Canadian literature in general.

What can English teachers do to help implement this change? First, put some of the French-Canadian books already available in translation onto our Canadian literature reading lists, and in this way begin to break down our cultural separatism.

More ambitiously, design courses and programs which truly reflect our cultural duality. We have a great deal to learn about one another in this country, and there is an interesting and totally unexplored field of comparative studies to be investigated here on many levels. Very often it is in learning more about others that we discover more about ourselves.

Thirdly, for those who are interested in seeing the present situation improve, bring pressure to bear on publishers, on government - individually, and through professional bodies large and small —, to have more translation made readily available. Many of the titles listed in my bibliography which are now out of print could and should be reissued in inexpensive editions. But they never will be unless there is some active demand for them.

Finally, here is the most challenging proposal I have to make to English teachers with regard to French-Canadian literature in translation: Do it yourself. 
Translation is not what many people who have never done any give it out to be. It is not a second-rate occupation. It is exhilirating, fascinating and creative. I know of no better way to learn and ever more sophisticated use of your own language. It is a sharing process, one which tests the finest of critical and interpretive faculties. It is putting into practice things that English teachers talk about endlessly on the theoretical level. It is all those things and more: It is a witty and amusing game.

I believe that every writer should try his hand at it, every Canadian writer in particular. But literary translation is not the exclusive preserve of the writer any more than it is the preserve of the technical translator. It calls for high powers of understanding and judgement, it calls for real skill in expression, and imaginative flair. English teachers are creative people, and this is the kind of challenge they could meet handsomely.

Translation is a bridge. I invite you all to use it, and to become bridge builders yourselves.

\section{A SELECTED BIBLIOGRAPHY}

I. Novel

AQuin, Hubert, Prochain épisode (1965), trans. Penny Williams, Prochain Episode, McClelland \& Stewart, 1967.

AUbert DE GASPÉ, Philippe, les Anciens Canadiens (1863), trans. G.M. Pennée, The Canadians of Old, Quebec, Desbarats, 1864. Trans. C.G.D. Roberts, The Canadians of Old, New York, Appleton, 1890.

Barbeau, Marius, le Rêve de Kamalmouk (1943), Mountain Cloud, Macmillan, 1944.

Bessette, Gérard, le Libraire (1960), trans. Glen Shortliffe, Not For Every Eye, Macmillan, 1962.

-, l'Incubation (1965), trans. Glen Shortliffe, Incubation, Macmillan, 1967.

Blais, Marie-Claire, la Belle Bête (1959), trans. Merloyd Lawrence, Mad Shadows, Mcclelland \& Stewart, 1960.

—, Tête Blanche (1960), trans. Charles Fullman, Tête-Blanche, McClelland \& Stewart, 1961.

-, le Jour est noir (1962), trans. Derek Coltman, The Day is Dark, Farrar, Strauss \& Giroux, 1967.

-, Une saison dans la vie d'Emmanuel (1965), trans. D. Coltman, A Season in the Life of Emmanuel, Farrar, Strauss \& Giroux, 1966.

Conan, Laure, A l'euvre et à l'épreuve (1891), The Master Motive, St. Louis, Herder, 1909.

Ducharme, Réjean, l'Avalée des avalés (1966), trans. Barbara Bray, The Swallower Swallowed, London, Hamish Hamilton, 1968.

ElIE, Robert, la Fin des songes (1950), trans. Irene Coffin, Farewell My Dreams, Ryerson, 1954.

FrÉCherte, Louis, le Noël au Canada (1900), trans. C.G.D. Roberts, Christmas in French Canada, Toronto, 1900.

France, Claire, les Enfants qui s'aiment (1956), trans. Antonia White, Children in Love, London, Eyre \& Spottiswoode, 1959.

GIGUÈRE, Diane, le Temps des jeux (1961), trans. Peter Green, Innocence, McClelland \& Stewart, 1966.

-, l'Eau est profonde (1965), Whirlpool, McClelland \& Stewart, 1966.

GodBout, Jacques, le Couteau sur la table (1965), trans. Penny Williams, Knife on the Table, McClelland \& Stewart, 1967.

GuÈYREMONT, Germaine, le Survenant (1945), trans. Eric Sutton, The Outlander, Toronto, McGraw-Hill, 1950.

-, Marie-Didace (1947), Monk's Reach, London, Evans Bros., 1950.

HaRveY, Jean-Charles, les Demi-civilisés (1929), trans. Lukin Barrette, Sackcloth for Banner, Macmillan, 1932.

HÉBERT, Jacques, les Ecourants (1966), trans. Gerald Taaffe, The Temple on the River, Montreal, Harvest House, 1967. 
HÉMoN, Louis, Maria Chapdelaine (1916), trans. W.H. Blake, Maria Chapdelaine, Macmillan, 1921. Trans. Andrew McPhail, Maria Chapdelaine, Montreal, Chapman, 1921.

JaSMIN, Claude, Ethel et le terroriste (1964), trans. David Walker, Ethel and the Terrorist, Montreal, Harvest House, 1965.

Langevin, André, Poussière sur la ville (1953), trans. John Latrebe and Robert Gottlieb, Dust Over the City, McClelland \& Stewart, 1955.

Lemein, Roger, Au pied de la pente douce (1944), trans. S. Putnam, The Town Below, New York, Reynal \& Hitchcock, 1948; NCL *, 1961.

- Les Plouffes (1948), trans. Mary Finch, The Plouffe Family, McClelland \& Stewart, 1950.

—, Pierre le magnifique (1952), trans. Harry Lorne Binsse, In Quest of Splendour, McClelland \& Stewart, 1955.

RINGUET, Trente arpents (1938), trans. Felix and Dorothea Walter, Thirty Acres, Macmillan, $1940 ; \mathrm{NCL}, 1960$.

RIVARD, Adjutor, Chez nous (1914), trans. W.H. Blake, Our Old Quebec Home, McClelland \& Stewart, 1924.

Roy, Gabrielle, Bonheur d'occasion (1945), trans. Hannah Josephson, The Tin Flute, McClelland \& Stewart, 1958; NCL, 1958.

-, la Petite poule d'eau (1950), trans. Harry Binsse, Where Nests the Water Hen, New York, Harcourt Brace, 1951; NCL, 1961.

-, Alexandre Chenevert (1954), trans. Harry Binsse, The Cashier, McClelland \& Stewart, 1955; NCL, 1963.

-, Rue Deschambault (1955), trans. Harry Binsse, Street of Riches, McClelland \& Stewart, 1957 ; NCL.

- la Montagne secrète (1961), trans. Harry Binsse, The Hidden Mountain, McClelland \& Stewart, 1962. - la Route d'Altamont (1966), trans. Joyce Marshall, The Road Past Altamont, McClelland
\& Stewart, 1967.

SAVARD, Félix-Antoine, Menaud, maître-draveur (1937), The Boss of the River, Ryerson, 1947. Thériault, Yves, Agaguk (1958), trans. Miriam Chapin, Agaguk, Ryerson, 1963.

—, Ashini (1961), Ashini, Ryerson.

\section{Short Fiction}

Aubry, Claude, The Magic Fiddler and Other Legends of French Canada, Peter Martin Associates, 1968.

Barbeau, Marius, "Selections ", trans. Michael Hornyanski, The Golden Phoenix, Oxford, 1960.

Darros, Louise, Contes étranges du Canada (1962), trans. Philippa C. Gerry, Strange Tales of Canada, Ryerson, 1965.

NANTEL, Adolphe, A la hache (1932), trans. B.K. Sandwell, A Saga of Lac Clair, privately printed, Montreal, 1937.

TACHÉ, Joseph-Charles, "Selection", trans. W.C. Woods, The Isle of the Massacre, Toronto, Publishers Syndicate Ltd., 1901.

III. Poetry

Garneau, Saint-Denys, from Poésies complètes (1949), trans. Jean Beaupré and Gail Turnbull, Nine Poems, Contact Press, 1953.

-, From Poésies complètes (1949), trans. F.R. Scott, Saint-Denys Garneau and Anne Hébert, Vancouver, Klanak Press, 1962.

GiguÈRE, Roland, from les Armes blanches and Amérique française (1954), trans. J. Beaupré and Gail Turnbull, Eight Poems, Contact Press, 1955.

HéberT, Anne, le Tombeau des rois (1953), trans. F.R. Scott, Saint-Denys Garneau and Anne Hébert, Vancouver, Klanak Press, 1962.

HéNaULT, Gilles, le Théâtre en plein air and Totems (1953), trans. J. Beaupré and Gail Turnbull, Seven Poems, Contact Press, 1953.

Lapornte, Paul-Marie, poèmes inédits, trans. J. Beaupré and G. Turnbull, Six Poems, Contact Press, 1953.

Nelligan, Emile, from Poésies complètes, trans. P.E. Widdows, Selected Poems, Ryerson, 1960.

$* \mathrm{NCL}=$ New Canadian Library 
See also:

DUDEk, Louis, Ed., Poetry of our Time, Macmillan, 1965. (Poems by Saint-Denys Garneau, Alain Grandbois, Anne Hébert, Gilles Vigneault, J.-G. Pilon.)

Marion, Séraphin, Ed., The Quebec Tradition; An Anthology of French-Canadian Prose and Verse, trans. Watson Kirkconnel1, Ed. Lumen, 1948.

Glassco, John, Ed. and Trans. An Anthology of French Canadian Poetry In Translation (working title), Oxford.

RoY, George Ross, Ed. and Trans. Twelve Modern French Canadian Poets, Ryerson, 1959.

IV. Drama

GÉlINAS, Gratien, Tit-Coq (1950), trans. Kenneth Johnstone and Gratien Gélinas, Tit-Coq, Clarke, Irwin.

-, Bousille et les justes (1960), trans. Kenneth Johnstone and Joffre Miville Dechêne, Bousi.le and the Just, Clarke, Irwin, 1961.

- Hier les enfants dansaient (1965), trans. Mavor Moore, Yesterday the Children Were Dancing, Clarke, Irwin, 1966.

V. Essay, Autobiography, Journal

Barbeau, Marius, J'ai vu Québec (1957), trans. Marius Barbeau, I Have Seen Quebec, Macmillan, 1957.

Chaput-Rolland, Solange, Chères Ennemies (1963), trans. Gwethalyn Graham, Dear Enemies, Macmillan, 1963.

-, Mon pays, Québec ou le Canada? (1967), My Country, Canada or Quebec? Macmillan, 1967.

Cloutier, Eugène, le Canada sans passeport (1967), trans. Joyce Marshall, No Passport, Oxford, 1968.

GARNEAU, Saint-Denys, Journal (1954), trans. John Glassco, Journal, McClelland \& Stewart, 1962.

Grandbois, Alain, Né à Québec (1933), Born in Quebec, Montreal, Palm Publishers, 1964.

LE Moyne, Jean, Convergences (1961), trans. Philip Stratford, Convergence, Ryerson, 1966.

Marie de l'InCarnation, Lettres, trans. Joyce Marshall, Word From New France, Oxford, 1967.

Martin, Claire, Dans un gant de fer (1965) and la Joue droite (1966), trans. Philip Stratford, In an Iron Glove, Ryerson, 1968.

Roquebrune, Robert de, Testament de mon enfance (1951), trans. Felix Walter, Testament of My Childhood, University of Toronto Press, 1964.

Tougas, Gérard, Histoire de la littérature canadienne-française, History of French Canadian Literature, Ryerson, 1967.

Philip Stratford 